\title{
Terapia pomalidomidem u pacjenta z 17-letnim wywiadem szpiczaka plazmocytowego
}

\author{
Pomalidomide therapy in a patient \\ with a 17-year history of plasma cell myeloma
}

\author{
Artur Jurczyszyn ${ }^{1}$, Magdalena Olszewska-Szopa ${ }^{2}$ \\ ${ }^{1}$ Katedra Hematologii, Collegium Medicum, Uniwersytet Jagielloński, Kraków \\ ${ }^{2}$ Oddział Kliniczny Hematologii, Samodzielny Publiczny Szpital Kliniczny, Wrocław, Polska
}

\begin{abstract}
Streszczenie
$W$ artykule opisano efekty leczenia pomalidomidem (POM) u pacjenta $z$ wieloletnim wywiadem szpiczaka plazmocytowego, po wielu liniach chemioterapii. Przytoczono dane z piśmiennictwa na temat skuteczności i bezpieczeństwa POM u pacjentów z oporna i nawrotowa postacia tej choroby.
\end{abstract}

Słowa kluczowe: szpiczak plazmocytowy, leczenie, pomalidomid

Hematologia 2017; 8, supl. A: A1-A3

Abstract

The article is dedicated to pomalidomide efficacy in heavily pretreated patient with a long term history of plasma cell myeloma. We provide the data on effectiveness and safety in relapsed and refractory myeloma.

Key words: plasma cell myeloma, treatment, pomalidomide

Hematologia 2017; 8, supl. A: A1-A3

\section{Wprowadzenie}

Pomalidomid (POM) to lek immunomodulujący (IMiD, immunomodulatory drug) - syntetyczna pochodna talidomidu. Podobnie jak inne leki $z$ tej grupy ma postać doustną i charakteryzuje się wielotorowym mechanizmem działania. Bezpośrednio przeciwnowotworowo działa, indukując apoptozę poprzez szlak czynnika jądrowego $\kappa \mathrm{B}(\mathrm{NF} \kappa \mathrm{B}$, nuclearfactor $\kappa \mathrm{B}$ ) i kaspazę 8. Hamuje adhezję komórek nowotworowych do komórek zrębu. Wzmacnia odpowiedź limfocytów Th1 i pobudza komórki naturalnej cytotoksyczności (NK, natural killer). Tłumi proliferację limfocytów T regulatorowych (Treg). Hamuje produkcję cytokin prozapalnych, takich jak czynnik martwicy nowotworu $\alpha$ (TNF $\alpha$, tumor necrosis factor $\alpha$ ) i interleukiny 6 (IL-6). Ponadto hamuje różnicowanie się osteoklastów. Podobnie jak starsze IMiD działa antyangiogennie [1].
W 2013 roku POM zaaprobowała amerykańska Agencja ds. Żywności i Leków (FDA, Food and Drug Administration) w szpiczaku opornym i nawrotowym (RRMM, relapsed/refractory multiple myeloma), kilka miesięcy później dopuszczono go w tym wskazaniu w Unii Europejskiej. W Polsce nie jest obecnie refundowany przez Narodowy Fundusz Zdrowia.

\section{Opis przypadku}

W maju 1999 roku w Klinice Hematologii Szpitala Uniwersyteckiego w Krakowie u 48-letniego mężczyzny rozpoznano szpiczaka plazmocytowego (PCM, plasma cell myeloma) IgG kappa w stopniu I według Międzynarodowego Indeksu Prognostycznego (ISS, International Staging System) oraz o stopniu zaawansowania IA według Durie-Salmona. W wywiadzie odnotowano

Adres do korespondencji: Artur Jurczyszyn, Katedra Hematologii, Collegium Medicum, Uniwersytet Jagielloński, ul. Kopernika 17, 31-501 Kraków, e-mail: mmjurczy@cyf-kr.edu.pl 
gorączkę reumatyczną i zapalenie stawów. W wykonanych przy rozpoznaniu badaniach laboratoryjnych stwierdzono podwyższone stężenie białka całkowitego - $85 \mathrm{~g} / \mathrm{l}$; w badaniu immunofiksacji krwi wykazano obecność białka monoklonalnego IgG kappa. W biopsji aspiracyjnej stwierdzono 23-procentowy naciek klonalnych plazmocytów. Nie wykazano odchyleń w morfologii ani osteolizy w badaniach radiologicznych układu kostnego. W leczeniu indukującym chory otrzymał 6 cykli VAD (winkrystyna, doksorubicyna, deksametazon), osiągając całkowitą remisję (CR) hematologiczną. Tandemowe autologiczne przeszczepienie krwiotwórczych komórek macierzystych (auto-HSCT, autologous hematopoietic stem cell transplantation), wykorzystując kondycjonowanie melfalanem w pełnych dawkach $200 \mathrm{mg} / \mathrm{m}^{2}$, przeprowadzono kolejno w grudniu 1999 roku oraz w maju 2000 roku, uzyskując CR. Od początku leczenia stosowano profilaktykę choroby kostnej kwasem pomidoronowym w dawce $90 \mathrm{mg}$ dożylnie co miesiąc przez 2 lata. Przez kolejne lata odbywały się regularne kontrole ambulatoryjne; pacjent pozostawal w CR. Wznowa choroby nastąpiła pod koniec 2005 roku. Wdrożono leczenie według schematu Thal-Dex (talidomid, deksametazon), które przerwano po 5 cyklach $z$ powodu polineuropatii obwodowej związanej $\mathrm{z}$ talidomidem. Od czerwca 2006 roku podano 4 kursy VMBCP (winkrystyna, melfalan, karmustyna, cyklofosfamid, prednizon), jednak bez efektu terapeutycznego; obserwowano progresję choroby. W styczniu 2007 roku rozpoczęto leczenie $z$ wykorzystaniem lenalidomidu (LEN). Po podaniu 7 cykli LEN-Dex przerwano leczenie $z$ powodu oporności na stosowane leki. W styczniu 2008 roku rozpoczęto terapię $z$ wykorzystaniem bortezomibu, glikokortykosteroidów oraz pegylowanej postaci doksorubicyny. Podano 2 cykle Vel-Caelyx-Dex w pełnych dawkach, uzyskując CR. Bortezomib pogłębił jednak polineuropatię obwodową. Przez kolejne lata chory był obserwowany w poradni hematologicznej. W maju 2011 roku podjęto próbę ponownej mobilizacji $z$ wykorzystaniem cyklofosfamidu, ale okazała się ona nieskuteczna. Wiosną 2012 roku doszło do kolejnego nawrotu choroby. Pacjenta zakwalifikowano do randomizowanego programu FOCUS: carfilzomib vs best supportive care (trafil do grupy poddanej terapii wspomagającej). Po 4 kursach stosowania cyklofosfamidu i Dex wycofał zgodę na udział w programie. W sierpniu 2012 roku otrzymał jeden cykl VMBCP, a następnie podano 1,5 kursu bortezomibu w zmniejszonej dawce ze względu na objawy ciężkiej polineuropatii. Uzyskano częściową remisję (PR, partial remission). Kolejna progresja choroby nastąpiła w lutym 2013 roku. Chorego leczono LEN oraz glikokortykosteroidami. Po podaniu 9 cykli LEN-Dex stwierdzono oporność na stosowane leczenie. Jesienią 2013 roku podano 5 cykli bendamustyny $z$ prednizonem, uzyskując PR. Następnie przeprowadzono skutecznie mobilizację $\mathrm{z}$ wykorzystaniem czynnika stymulującego tworzenie kolonii granulocytów (G-CSF, granulocyte-colony stimulating factor) i pleriksaforu, uzyskując $4,08 \times 10^{6} / \mathrm{kg} \mathrm{mc}$. CD34+. W styczniu 2014 roku, gdy pacjenta przygotowywano do kolejnej procedury auto-HSCT, ponownie doszło do progresji choroby. W marcu 2014 roku podano 2 dawki karfilzomibu $z$ glikokortykosteroidami, ale obserwowano nietolerancję karfilzomibu. W kwietniu 2014 roku chorego zakwalifikowano do leczenia POM. Od kwietnia 2014 roku do lutego 2016 r. pacjent otrzymał 19 cykli POM z Dex (ryc. 1);

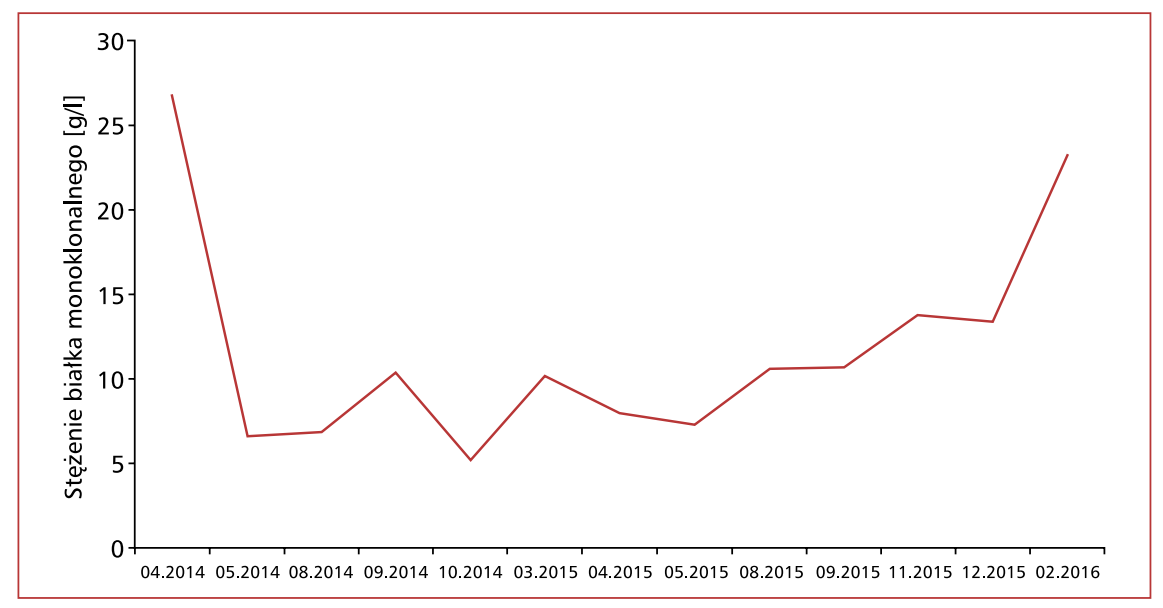

Rycina 1. Ocena stężenia białka $M-19$ cykli POM-Dex (pomalidomid, deksametazon) 
POM w dawce 4 mg uzyskano nieodpłatnie od producenta. Terapia była dobrze tolerowana. Uzyskano bardzo dobrą częściową odpowiedź (VGPR, very good partial remission), a następnie stabilizację choroby.

W czerwcu 2015 roku u chorego zdiagnozowano dodatkowo raka gruczołu krokowego cT2bN0M0 — przebył radykalną radioterapię 70,2 Gy w 26 frakcjach $z$ efektem CR. Po stwierdzeniu progresji choroby, od lutego 2016 rok do czerwca 2016 roku, chorego leczono daratumumabem $\mathrm{w}$ monoterapii, $\mathrm{w}$ dawce $16 \mathrm{mg} / \mathrm{kg} \mathrm{mc}$., początkowo $\mathrm{z}$ dobrą reakcją, ale po 5 miesiącach doszło do kolejnej progresji szpiczaka. Wówczas zdecydowano o zastosowaniu terapii paliatywnej w postaci postępowania wspomagającego. Chory zmarł we wrześniu 2016 roku, w wieku 65 lat, po 17 latach walki z chorobą.

\section{Dyskusja}

Ostatnie lata przyniosły wiele dowodów na skuteczność i bezpieczeństwo POM u chorych z RRMM. Dotychczas najlepiej zbadano synergistyczne skojarzenie POM z Dex. W badaniu III fazy MM-003 porównano skuteczność POM $z$ małą dawką Dex w stosunku do dużych dawek Dex u pacjentów $z$ RRMM. Badaniem objęto 455 chorych opornych na LEN i bortezomib. Dołączenie POM wyraźnie wydłużało nie tylko czas do progresji choroby (PFS [progression-free survival]: $4 v .1,9$ mies.; $\mathrm{p}<0.0001$ ), ale też całkowite przeżycie chorych (OS [overall survival]: 13.1 v. 8.1 mies.; $\mathrm{p}<0,009)[2]$.

Pomalidomid w połączeniu $z$ DEX przełamuje negatywny wpływ obciązających czynników cytogenetycznych, takich jak del $17 \mathrm{p}$ oraz $\mathrm{t}(4 ; 14)$, co wykazano w badaniach MM-003 [2] oraz IFM 2010-02 [3]. Natomiast główne działania niepożądane POM, spowodowane hamującym wpływem na szpik, to niedokrwistość, neutropenia oraz małopłytkowość. Ponadto najczęściej obserwuje się zmęczenie [1].

Badane są trójlekowe schematy $z$ zastosowaniem POM. W badaniu I fazy skojarzono go $z$ karfilzomibem oraz Dex (CPD [karfilzomib, pomalidomid, deksametazon]). Wszyscy chorzy wykazywali oporność na wcześniej stosowany LEN. U połowy (16/32 osób) uzyskano co najmniej PR, a u 41\% (13/32 osób) co najmniej stabilizację choroby [4]. Trwa badanie kliniczne III fazy (MM-007) nad skutecznością połączenia POM $z$ bortezomibem i Dex. Prowadzone są również badania nad schematami czterolekowymi $z$ udziałem elotuzumabu.

Dowiedziono, że w przeciwieństwie do LEN dawki POM nie trzeba modyfikować u pacjentów z upośledzeniem funkcji nerek [5]. Co więcej, POM poprawia wyniki leczenia $\mathrm{w}$ tej grupie chorych $[6,7]$.

\section{Podsumowanie}

Pomalidomid to lek o dobrym profilu bezpieczeństwa, który w skojarzeniu $z$ glikokortykosteroidami przynosi korzyści pacjentom $z$ RRMM. Pozytywne efekty terapii obserwuje się również w grupach pacjentów $z$ negatywnymi czynnikami cytogenetycznymi i niewydolnością nerek. Połączenia POM z 2 lub nawet 3 lekami wymagają dalszych badań, ale uzyskane dotychczas wyniki są zachęcające.

\section{Piśmiennictwo}

1. Lacy M.Q., McCurdy A.R. Pomalidomide. Blood 2013: 122: 2305-2309 .

2. Dimopoulos M.A., Weisel K.C., Song K.W. i wsp. Cytogenetics and long-term survival of patients with refractory or relapsed and refractory multiple myeloma treated with pomalidomide and low-dose dexamethasone. Haematologica 2015; 100: 11327-11333.

3. Leleu X., Karlin L., Macro M. i wsp. Pomalidomide plus low-dose dexamethasone in multiple myeloma with deletion $17 \mathrm{p}$ and/or translocation (4;14): IFM 2010-02 trial results. Blood 2015; 125 : 1411-1417.

4. Shah J.J., Stadtmauer E.A., Abonour R. i wsp. Carfilzomib, pomalidomide, and dexamethasone for relapsed or refractory myeloma. Blood 2015; 126: 2284-2290.

5. Matous J., Siegel D., Lonial S. i wsp. MM-008: a phase 1 trial evaluating pharmacokinetics and tolerability of pomalidomide low-dose dexamethasone in patients with relapsed or refractory and refractory multiple myeloma and renal impairment. Blood 2014; 124: 4730 .

6. Weisel K.C., Dimopoulos M.A., Moreau P. i wsp. Analysis of renal impairment in MM-003, a phase III study of pomalidomide + low-dose dexamethasone versus high-dose dexamethasone in refractory or relapsed and refractory multiple myeloma. Haematologica 2016; 101: 872-878.

7. Maciocia N., Melville A., Cheesman S. i wsp. Real-world use of pomalidomide and dexamethasone in double refractory multiple myeloma suggests benefit in renal impairment and adverse genetics: a multi-centre UK experience. Br. J. Haematol. 2017; 176: 908-917. 